\title{
Mature leaf concentrate of Sri Lankan wild (1) crosshark type Carica papaya Linn. modulates nonfunctional and functional immune responses of rats
}

Chanika Dilumi Jayasinghe ${ }^{1}$, Dinara S Gunasekera², Nuwan De Silva², Kithmini Kawya Mandakini Jayawardena ${ }^{3}$ and Preethi Vidya Udagama ${ }^{1 *}$

\begin{abstract}
Background: The leaf concentrate of Carica papaya is a traditionally acclaimed immunomodulatory remedy against numerous diseases; nonetheless comprehensive scientific validation of this claim is limited. The present study thus investigated the immunomodulatory potential of Carica papaya mature leaf concentrate (MLCC) of the Sri Lankan wild type cultivar using nonfunctional and functional immunological assays.

Methods: Wistar rats ( $N=6$ / group) were orally gavaged with 3 doses $(0.18,0.36$ and $0.72 \mathrm{ml} / 100 \mathrm{~g}$ body weight) of the MLCC once daily for 3 consecutive days. Selected nonfunctional (enumeration of immune cells and cytokine levels) and functional (cell proliferation and phagocytic activity) immunological parameters, and acute toxic effects were determined using standard methods.

Effect of the MLCC $(31.25,62.5,125,250,500$ and $1000 \mu \mathrm{g} / \mathrm{ml})$ on ex vivo proliferation of bone marrow cells (BMC) and splenocytes (SC), and in vitro phagocytic activity of peritoneal macrophages (PMs), and their corresponding cytokine responses were evaluated. The phytochemical profile of the MLCC was established using liquid chromatography-mass spectrometry (LS-MS) and Gas chromatography-mass spectrometry (GC-MS).

Results: Counts of rat platelets, total leukocytes, lymphocyte and monocyte sub populations, and BMCs were significantly augmented by oral gavage of the MLCC $(p<0.05)$. The highest MLCC dose tested herein significantly reduced pro inflammatory cytokines, Interleukin 6 (IL-6) and Tumor Necrosis Factor a (TNF a) levels of rats $(p<0.05)$.

The in vivo phagocytic index of rat PMs significantly increased by oral gavage of all three doses of the MLCC $(p<0.05)$. In vitro phagocytic activity of rat PMs were enhanced by the MLCC and triggered a Th1 biased cytokine response. The MLCC at low concentrations elicited ex vivo proliferation of BMC $(31.25 \mu \mathrm{g} / \mathrm{ml})$ and SC $(31.25 \mathrm{and} 62.5 \mu \mathrm{g} / \mathrm{ml})$ respectively. Conversely, high concentrations (500 and $1000 \mathrm{\mu g} / \mathrm{ml}$ ) exhibited cytotoxicity of both BMC and SC with significant modulation of cytokines. Chemical profile of the MLCC revealed the presence of several immunomodulatory compounds. The oral gavage of the MLCC was found to be safe in terms of both hepatic and renal toxicities.

Conclusion: The present study established that the mature leaf concentrate (MLCC) of Carica papaya Sri Lankan wild type cultivar is orally active, safe and effectively modulates nonfunctional and functional immunological parameters of rats that unequivocally corroborate the traditional medical claims.
\end{abstract}

Keywords: Carica papaya, Sri Lankan wild type cultivar, Mature leaf concentrate, Immunomodulation, Immune cell counts, Phagocytosis, Cytokines

\footnotetext{
* Correspondence: preethi@zoology.cmb.ac.lk

'Department of Zoology \& Environment Sciences, Faculty of Science,

University of Colombo, Colombo 3, Sri Lanka

Full list of author information is available at the end of the article
}

(c) The Author(s). 2017 Open Access This article is distributed under the terms of the Creative Commons Attribution 4.0 International License (http://creativecommons.org/licenses/by/4.0/, which permits unrestricted use, distribution, and reproduction in any medium, provided you give appropriate credit to the original author(s) and the source, provide a link to the Creative Commons license, and indicate if changes were made. The Creative Commons Public Domain Dedication waiver (http://creativecommons.org/publicdomain/zero/1.0/) applies to the data made available in this article, unless otherwise stated. 


\section{Background}

Pharmacological manipulation of the immune system is emerging as a novel approach in managing human diseases. There is a recent spurt in the interest of identification of immunomodulatory leads of herbal origin which are safe, efficient and economical in chronic usage.

The immune system is an ensemble of complex defense mechanisms functioning at different levels, from an individual cell to the whole organism [1]. Hence, imbalance of the immune homeostasis is implicated in the onset and progression of chronic ailments [2]. An overactive immune system is associated with autoimmunity, chronic inflammatory diseases, systemic vasodilatation and carcinogenesis [3, 4].Conversely, immunosupression increases the susceptibility to infection and is implicated in tumor development $[5,6]$.

The clinical concept of immunomodulation focuses on stimulating both innate and adaptive arms of immunity or suppressing excessive immune function using exogenous therapeutic agents [2]. Synthetic cytotoxic drugs (cyclophosphamide, methotrexate and 5-fluorouracil), recombinant cytokine therapy, and antibody therapy are established in allopathic medicine as immunotherapy against cancers and autoimmune diseases [7]. However, the occurrence of adverse events and high costs of these have generated barriers to successful therapeutic applications [8]. In this regard, plant based immunomodulators are advantageous considering their pleotropic activity, less side effects and cost effectiveness.

Since ancient times, medicinal plants have been used virtually in all cultures as sources of medicines to improve the immune system. Recently, advancements in immunological techniques enabled the characterization of medicinal plants in unprecedented detail. Numerous plant species such as Aloe vera, Withania somnifera, Allium sativum, Ocimum sanctum, Azadirachita indica and many others have been scientifically justified for their immunomodulatory activity together with possible mechanistics [9].

Carica papaya, (Common name- paw paw) belongs to family Caricaceae and is one of the most popular and economically important plants in the world as a food source and as a herbal medicine [10]. It is native to the tropics of the Americas but now is cultivated worldwide as a fruit crop [10].

Different parts of $C$. papaya has been traditionally claimed as therapeutics for a broad range of diseases [10]. Particularly the leaf extract/concentrate has been scientifically investigated for pharmacological properties such as anti-microbial, anti-parasitic (antimalarial) activity, anti-cancer, anti-inflammatory and membrane stabilization properties [10].

In Sri Lankan traditional medicine the leaf juice of $C$. papaya is claimed as a powerful remedy for modulating the immune system (Personal communication- Dr. Pathum Jayaweera, Sri Lankan traditional medical practitioner). Thus far several in vitro and in vivo experiments have been carried out to investigate the immuno pharmacological properties of the leaf concentrate of C. papaya.

Our group for the first time, established the platelet and total white blood cell (WBC) increasing activity of the mature leaf concentrate of $C$. papaya of the red lady cultivar grown in Sri Lanka using hydorxyurea induced thrombocytopenic Wistar rat model as well as in normal counterpart rats [11]. Concurrently, we observed pronounced anti-inflammatory activity of this preparation indicating immunomodulatory potential [11]. Similarly, oral gavage of papaya leaf extract exhibited a significant platelet and WBC increasing activity in immunosuppressive rats using cyclophosphamide [12] and ansgrelide (thrombocytopenic drug) [13].

Dharmarathna et al. [14] observed a marked platelet count elevation in none thrombocytopenic mice following the oral treatment of $C$. papaya extract for seven days [14]. Another study conducted using non thrombocytopenic rats reported a marked increment in platelet counts, mean cell haemoglobin $(\mathrm{MCH})$ and mean corpuscular volume $(\mathrm{MCV})$ following the oral treatment with this leaf formulation for 7 days [15].

In addition to animal experimentation, the platelet increasing activity of papaya leaf extract has been validated in thrombocytopenia associated dengue patients. An open labeled randomized controlled trial carried out with 228 patients $($ Treatment $=111$, Control $=117$ ) with dengue fever (DF) and dengue haemorrhagic fever (DHF) revealed a significant increase of platelet counts after 40 and $48 \mathrm{~h}$ of oral administration of C. papaya leaf juice for 3 consecutive days [16]. A pilot study reported an increase of platelet and WBC counts of dengue patients after $24 \mathrm{~h}$ of administration of papaya leaf juice and patients recovered without hospital admission [17]. A similar effect was also observed in an open labeled randomized controlled trial with 30 dengue patients treated with a tablet (Caripill) prepared from $C$. papaya leaf extract [18]; A significant increase of platelet counts was observed following oral treatment with this tablet three times daily for five days and exerted fewer side effects and good tolerability.

Although, a wealth of information is available on platelet increasing activity of different extracts of $C$. papaya leaves, a comprehensive account on immunomodulatory potential is limited. Otsuki et al. [19] reported immunomodulatory potential of the aqueous extract of $C$. papaya leaf using in vitro culture of human peripheral blood mononuclear cells (PBMCs).

When PBMCs were treated in vitro with $C$. papaya aqueous extract, Interleukin 2 and 4 (IL-2 and IL-4) secretion were attenuated whereas that of Interleukin 
12p40, 12p70 (IL- 12p40, IL-12p70), Interferon Gamma (IFN- $\gamma$ ) and Tumor Necrosis Factor alpha (TNF- $\alpha$ ) was enhanced without growth inhibition [19]. Moreover, microarray analyses showed the expression of $23 \mathrm{immu-}$ nomodulatory genes of PBMC [20].

Tomar et al. [21] reported oral administration of alcoholic extract of papaya leaf (50-200 mg/kg) had stimulated both innate and humoral immune responses of Bagg Albino laboratory bred (BALB/c) mice.

Although, the immunomodulatory potential of different C. papaya extracts (aqueous and alcohol) was adequately demonstrated in the above in vitro and in vivo studies, a comprehensive account of the effect of the mature leaf concentrate of $C$. papaya leaf both on nonfunctional and functional immune responses may strongly warrant the development of a potential drug lead.

Thus, the present study specifically aimed at investigating the effect of MLCC on nonfunctional (immune cell counts and cytokine levels) and functional (cell proliferation and phagocytosis) immunological parameters of rats. Further, liver and kidney function parameters were examined to envisage the safety of oral administration of the MLCC. Moreover, the chemical profile of the MLCC was investigated using liquid chromatography-mass spectrometry (LC-MS) and Gas chromatography-mass spectrometry (GC-MS).

A preliminary study on platelet increasing activity revealed that the Sri Lankan wild type $C$. papaya variety possessed more potent platelet increasing activity than the hybrid cultivars such as red lady (unpublished data). Thus, leaves of the Sri Lankan wild type cultivar of $C$. papaya were used in this study.

\section{Methods}

\section{Chemicals and reagents}

Pyrosate Limulus amebocyte lysate (LAL) endotoxin determination kit was purchased from Associates for Cape Code Incorporated (E.Saint Jean Drive.E.Falmouth, MA, 02536 USA). Sandwich, Enzyme Linked Immunosorbent Assay (ELISA) kits to assess rat Interleukin 6 (IL-6) and 10 (IL-10), Interferon gamma (IFN $\gamma$ ) and Tumor Necrosis Factor alpha (TNF- $\alpha)$ were purchased from BD Bio sciences (Torreyana Rd., San Diyego, 92,121, CA). The cell culture medium and reagents were purchased from different sources, Roswell Park Memorial Institute (RMPI) 1640, from Gibco BRL Life Technologies (Grand Island, NY, USA) Fetal bovine serum (FBS), streptomycine-penicilline antibiotics, cell culture grade sodium biocarobonate, dimethyl sulfoxide (DMSO), 4,5-dimethylthiazole-2-yl)2,5-diphenyltetrazolium bromide (MTT), Nitro blue tetrazolium (NBT) were purchased from Sigma Aldrich Co., Ltd. (St. Louis, MO, USA).

LC-MS grade methanol, formic acid and common commercial grade chemicals, ethanol, isopropanol, hydrochloric acid, ammonium oxalate, acetic acid were purchased from Sigma Aldrich Co. Ltd. (St. Louis, MO, USA). For LC-MS analysis water was purified by a Milli-Q purification system from Evoqua Water Technologies.

\section{Collection of plant material}

Mature leaves (5th leaf from the apex) of Carica papaya (Local name: Sinhala: papol, gaslabu; Tamil: pappali, pappayi; English: Paw paw, Papaya) of the Sri Lankan wild type cultivar were collected from a home garden in Kadawatha, Gampaha district in Sri Lanka (longitude-79 $57^{\prime} 0^{\prime \prime}$ E,latitude- $7^{\circ} 4^{\prime} 0^{\prime \prime} \mathrm{N}$ ) during April 2014 to June 2015. The specimen was identified and authenticated by Dr. $H$ Kathriarachchi of the Department of Plant Sciences of the University of Colombo, Sri Lanka. A voucher specimen (No- 120) was deposited at the Department of Zoology and Environment Sciences, University of Colombo, Sri Lanka.

\section{Preparation of mature leaf concentrate}

The mature leaf concentrate of $C$. papaya (MLCC) was prepared essentially following the procedure described in [11] with slight modifications. Briefly, fresh mature leaves of $C$. papaya (wild type cultivar) were thoroughly washed under running tap water, blotted dried and after removal of petioles and primary veins, leaf blades were pulverized using a mechanical juice extractor (HR,1861, Philips, Hong Kong) without adding water (at $10 \mathrm{~g}$ leaf blade/ $\mathrm{ml}$ of concentrate). The test animals were orally gavaged directly with the fresh MLCC at doses of $0.18,0.36$ and $0.72 \mathrm{ml} / 100 \mathrm{~g}$ of body weight (BW) of rats representing low, mid (human equivalent) and high doses, respectively [11]. For the in vitro assays, the extract was filtered $(0.22 \mu \mathrm{m}$ Millipore filter, 290 Concord Rd, Billerica, MA, USA) and concentrations were calculated by extrapolating the dry weight of the MLCC.

\section{Detection of endotoxins}

The fresh MLCC was screened for endotoxin contamination using the Limulus Amebocyte Lystate (LAL) gel-clot test according to the manufactures instructions (the Pyrosate ${ }^{\oplus}$ Kit, Associates for Cape Code Incorporated,124 Bernard E.Saint Jean Drive.E.Falmouth, MA,02536 USA).

\section{Experimental animals}

Healthy, adult male and female Wistar rats (180-230 g of weight) purchased from the Medical Research Institute, Colombo, Sri Lanka were used in this study. All animals received humane care. They were housed in plastic cages in the animal house of the Department of Zoology and Environment Sciences, University of Colombo under standard animal house conditions (temperature; $28-31{ }^{\circ} \mathrm{C}$, photoperiod; approximately $12 \mathrm{~h}$ natural light per day, 
relative humidity: 50-55\%). The animals were fed with pelleted food (VET HOUSE Ltd. Colombo, Sri Lanka) and clear drinking water ad libitum. Ethical approval for the laboratory animal study was obtained from the Institute of Biology, Sri Lanka (Ethical approval number -IOBSL 111 05 29). Hence, all experiments conducted were in compliance with the Organization for Economic Co-operation and Development (OECD) guidelines.

\section{Effects of the MLCC on nonfunctional immunological parameters of rats \\ Enumeration of immune cells}

Four separate groups of adult male Wistar rats $(N=6$ / group) were orally gavaged with distilled water (DW) as the control, three doses of the MLCC at 0.18, 0.36 and $0.72 \mathrm{ml} / 100 \mathrm{~g} \mathrm{BW}$ of rats, once daily for three consecutive days. On day 3 post treatment, rats were anesthetized under high dose of ether and blood was collected by cardiac puncture and dispensed into ethylenediaminetetra acetic acid (EDTA) containing tubes. Platelets, and total and differential white blood cell counts were established according to [22]. Femur and spleen were aseptically excised from sacrificed rats and placed in glass vials containing $5 \mathrm{ml}$ of phosphate buffered saline (PBS). Spleen was macerated in PBS to release the splenocytes (SC), and bone marrow cells (BMC) were separated by flushing PBS through the femur; SC and BMC counts were made using a Neubauer's improved Haemocytometer (B.S 748, Weiber, England) [22].

\section{Plasma cytokine levels}

Two separate groups of rats $(N=6 /$ group $)$ were orally administrated with the highest dose $(0.72 \mathrm{ml} / 100 \mathrm{~g} \mathrm{BW})$ of the MLCC and DW as the control once daily for three consecutive days. On day 3 post treatment, blood was collected by heart puncture and dispensed into EDTA tubes. Anticoagulated blood was immediately centrifuged at $750 \mathrm{x}$ g for $10 \mathrm{~min}$ to separate plasma [22]. The plasma cytokine levels of IL-6, TNF- $\alpha$, IFN- $\gamma$ and IL-10 in both treated and control groups were quantified using rat sandwich ELISA kits according to the manufacturer's instructions (BD Bio science, Torreyana Rd., San Diyego, CA 92121).

\section{Effects of the MLCC on functional immunological parameters of rats \\ Neutral red dye uptake assay}

Functional immunological test based on phagocytic activity was measured using neutral red dye uptake assay [22]. In brief, peritoneal macrophages (PMs) were aspirated from the rats treated with the three doses of the MLCC (low: $0.18 \mathrm{ml}$, mid: $0.36 \mathrm{ml}$ and high: $0.72 \mathrm{ml} / 100$ $\mathrm{g} \mathrm{BW}$ ) into $10 \mathrm{ml}$ of PBS [22]. The cell suspension was centrifuged at $500 \mathrm{x}$ g for $5 \mathrm{~min}$ at RT and the resultant cell pellet was dissolved in $1 \mathrm{ml}$ of PBS. Two drops of $1 \%$ Neutral Red (in PBS) were added to the cell suspension and PMs with ingested red dye particles were counted using a Neubauer imporved haemocytometer (B.S 748, Weiber, England). The phagocytic index was calculated as follows [22]:

$$
\text { Phagocytic index }=\frac{\text { Number of active PM cells }}{\text { Number of total PM cells }} \times 100 \%
$$

In vitro phagocytic activity and cytokine profile of rat peritoneal macrophages

\section{Preparation of rat peritoneal macrophages (PMs)}

Five milliters of FBS was injected intraperitoneally into rats as a stimulant to elicit PMs [23]. Three days later, the peritoneal exudate was collected by peritoneal lavage with $10 \mathrm{ml}$ of complete RPMI 1640 (CRPMI) medium supplemented with $50 \mu \mathrm{M}$ 2-mercapthoethanol.

\section{NBT dye reduction assay}

In vitro phagocytic activity of rat immune cells was established by the nitrobluetetrazolium (NBT) reduction assay [23]. Twenty microliters of complete RPMI 1640 (CRPMI; Control), different concentrations of the MLCC $(31.25,62.5,125,250,500$ and $1000 \mu \mathrm{g} / \mathrm{ml}), 20 \mu \mathrm{l}$ of the PM suspension and $40 \mu \mathrm{l}$ of CRPMI medium were added to wells of a 96-well plate (Corning, Sigma,USA). After incubation for $24 \mathrm{~h}$ at $37{ }^{\circ} \mathrm{C}$ in $5 \% \mathrm{CO}_{2}$ humidified atmosphere, $20 \mu \mathrm{l}$ of a heat inactivated yeast (Saccharomyces cerevisiae $)$ suspension $\left(5 \times 10^{7}\right.$ particles $\left./ \mathrm{ml}\right)$ and $20 \mu \mathrm{l}$ of $1.5 \mathrm{mg} / \mathrm{ml} \mathrm{NBT}$ in PBS were dispensed and the mixture was further incubated under the same conditions.

After incubation for $60 \mathrm{~min}$, the adherent cells were rinsed vigorously with CRPMI medium and washed four times with $200 \mu \mathrm{l}$ methanol. After air-drying, $120 \mu \mathrm{l}$ of $2 \mathrm{M}$ potassium hydroxide $(\mathrm{KOH})$ and $140 \mu \mathrm{l}$ of DMSO was added. The absorbance was measured at $570 \mathrm{~nm}$ using a micro plate reader (Microplate reader 680, Bio-Rad, USA) and the percentage of NBT reduction representing phagocytic activity was calculated using the following equation [23]:

$$
\text { Phagocytic activity }(\%)=\frac{[\text { OD sample-OD negative control }]}{\text { OD negative control }} \times 100
$$

\section{Cytokine profiling of PM cell cultures}

Briefly, $40 \mu \mathrm{l}$ CRPMI (Control), different concentrations of the MLCC $(31.25,62.5,125,250,500$ and $1000 \mu \mathrm{g} / \mathrm{ml}), 20 \mu \mathrm{l}$ of the PM suspension and $40 \mu \mathrm{l}$ of CRPMI medium were cultured in wells of a flat bottom 96-well plate (Corning, Sigma, USA). After incubation for $24 \mathrm{~h}$ at $37^{\circ} \mathrm{C}$ in $5 \% \mathrm{CO}_{2}$ humidified atmosphere, $20 \mu \mathrm{l}$ of a heat inactivated yeast (Saccharomyces cerevisiae) 
suspension $\left(5 \times 10^{7}\right.$ particles $\left./ \mathrm{ml}\right)$ and $40 \mu \mathrm{l}$ of CRPMI were added and incubated at the same condition for another $1 \mathrm{~h}$. Cultures were centrifuged at $1000 \mathrm{x}$ g at $4{ }^{\circ} \mathrm{C}$ for $10 \mathrm{~min}$ and the resultant supernatants were analysed for IFN- $\gamma$ and IL-10 using rat sandwich ELISA kits according to the manufacturer's instructions (BD Bio science, Torreyana Rd., San Diyego, CA 92121).Viable cells of each concentration were calculated using trypan blue dye exclusion assay [20] and cytokine levels were normalized to the viable cell count.

\section{Ex vivo proliferation and cytokine profiling of rat immune cells \\ Preparation of rat bone marrow cells (BMC) and splenocytes (SC)}

Femurs and spleens were aseptically excised from scarified Wistar rats. Bone marrow cells were obtained by flushing PBS through the femur bone cavity [22]. Spleens were collected into PBS and the SCs were gently released. Both cell suspensions [22] were centrifuged at $300 \mathrm{x} \mathrm{g}$, at $25{ }^{\circ} \mathrm{C}$ for $10 \mathrm{~min}$ [24]. The erythrocytes in the cell suspensions were then lysed by hypotonic solution $(0.2 \% \mathrm{NaCl})$ and the cells were resuspended in $1.6 \%$ $\mathrm{NaCl}$ to restore the isotonicity [23]. Cell suspensions were washed twice with CRPMI medium supplemented with $10 \%$ heat-inactivated FBS, $100 \mathrm{U}$ penicillin, and $100 \mu \mathrm{g} / \mathrm{l}$ streptomycin [23, 24]. The cell numbers were adjusted to $10^{6}$ cells $/ \mathrm{ml}$ using a Neubauer's improved haematocytometer (B.S 748, Weiber, England). Trypan blue dye exclusion assay was performed to assess the viability of both cell types [20].

\section{MTT based cell proliferation assay}

The in vitro cell proliferation assay was carried out using 4,5-dimethylthiazole-2-yl)-2,5-diphenyltetrazolium bromide (MTT) assay without mitogenic stimulation [24, 25]. Briefly, $20 \mu \mathrm{l}$ of CRPMI as the control and various concentrations of the MLCC $(31.25,62.5,125,250,500$ and $1000 \mu \mathrm{g} / \mathrm{ml}$ ) and $2 \mu \mathrm{g} / \mathrm{ml}$ Lipopolysaccharides (LPS) as a positive control were added to $20 \mu \mathrm{l}$ of BMC or SC cell suspensions $\left(10^{6}\right.$ cells $\left./ \mathrm{ml}\right)$. Another $40 \mu \mathrm{l}$ of CRPMI was added to the 96- well plate (Corning, Sigma,USA) and incubated at $37{ }^{\circ} \mathrm{C}$ in a humidified $5 \% \mathrm{CO}_{2}$ atmosphere for $48 \mathrm{~h}$. Subsequently, $20 \mu \mathrm{l}$ of MTT $(5 \mathrm{mg} / \mathrm{ml})$ in PBS and $40 \mu \mathrm{l}$ of RPMI was added. The culture medium was removed by aspiration and $100 \mu \mathrm{l}$ of $0.04 \mathrm{M}$ hydrochloride acid $(\mathrm{HCl})$ in isopropyl alcohol were added to lyse the cells. Following the addition of $100 \mu \mathrm{l}$ of distilled water absorbance was measured at $570 \mathrm{~nm}$ using a micro plate reader (Microplate reader 680, Bio-Rad, USA) and the \% cell proliferation was calculated using the following equation [23, 24]:
Cell proliferation $(\%)=\frac{[\mathrm{OD} \text { of treated-OD of control }]}{\text { OD of control }} \times 100$

\section{Cytokine profiling of rat BMC and SC cultures}

Briefly, $40 \mu \mathrm{l}$ of BMC or SC suspension was cultured with $40 \mu \mathrm{l}$ of CRPMI (control) and different concentrations of the MLCC $(31.25,62.5,125,250,500$ and $1000 \mu \mathrm{g} / \mathrm{ml}$ ) and $120 \mu \mathrm{l}$ of CRPMI in a 96 well plate for $48 \mathrm{~h}$. Culture medium of each well was collected, centrifuged at $1000 \mathrm{x}$ g at $4{ }^{\circ} \mathrm{C}$ for $10 \mathrm{~min}$ and the supernatants were subjected to cytokine analyses. Cytokine levels were quantified using rat sandwich ELISA kits according to the manufacture's instructions (BD Bio science, Torreyana Rd., San Diyego, CA 92121). Viable cells of each concentration were calculated using trypan blue dye exclusion assay [20] and cytokine levels were normalized to the viable cell count.

\section{Acute toxicity of the MLCC on rats}

Hepato and nephro toxic parameters were measured in rats $(n=6)$ treated for three consecutive days with the highest dose $(0.72 \mathrm{ml} / 100 \mathrm{~g} \mathrm{BW})$ of the MLCC compared with the control group. Serum parameters such as aspartate transaminase (AST), alanine transaminase (ALT), urea, blood urea nitrogen (BUN), creatinine levels were determined using Randox kits (Randox Laboratories Ltd., Co. Antrium, U.K) and the spectrophotometer (JASCO V560, Jasco Corporation, Tokyo, Japan) as per manufacturer's instructions [26].

\section{Chemical profiling of the MLCC LC-MS analysis}

LC-MS analysis were performed on a Waters e2695 instrument equipped with a photodiode array (PDA) detector (model 2998,). The separations were carried out on a reversed phase column (Waters Spherisorb $5 \mu \mathrm{m}$ ODS2, $4.6 \times 250 \mathrm{~mm}$ ) maintained at $20{ }^{\circ} \mathrm{C}$. The sample was scanned from 200 to $800 \mathrm{~nm}$ with a resolution of $1.2 \mathrm{~nm}$.

The mobile phase consisted of $50 \%$ of solvent A $(0.1 \% v / \mathrm{v}$ of formic acid in water) and $50 \%$ of solvent B $(0.1 \% \mathrm{v} / \mathrm{v}$ of formic acid in methanol) at a flow rate of $500 \mu \mathrm{l} / \mathrm{min}$ for 30 min under isocratic conditions.

\section{GC-MS analysis}

GC-MS studies were carried out using Agilent 7890B GC system and MS of 5977A Mass Selective Detector (MSD). The separations were carried out on Agilent HP-5 ms ultra inert column $(30 \mathrm{~m} \times 250 \mu \mathrm{m} \times 0.25 \mu \mathrm{m})$. Initial temperature for the $\mathrm{GC}$ analysis was $50{ }^{\circ} \mathrm{C}$ (held for $5 \mathrm{~min}$ ), which was raised to $230{ }^{\circ} \mathrm{C}\left(\operatorname{ramp} 20^{\circ} \mathrm{C} / \mathrm{min}\right)$. The $230{ }^{\circ} \mathrm{C}$ temperature was maintained for $10 \mathrm{~min}$. The sample $(1 \mu \mathrm{l})$ was injected using split-less mode with an 
inlet temperature of $260{ }^{\circ} \mathrm{C}$. Helium was used as the carrier gas with a flow rate of $2 \mathrm{ml} / \mathrm{min}$. MS transfer line temperature was maintained at $260{ }^{\circ} \mathrm{C}$. The assignment of the peaks is based on the National Institute of Standards and Technology (NIST) reference database.

\section{Statistical analyses}

Data were expressed as Mean \pm SEM (Standard error of means). The in vitro experiments were examined in three individual experiments, performed in triplicate for each concentration. One-way Analysis of variance (ANOVA) followed by post-hoc Tukey HSD Calculator were used for multiple comparison.

In vivo experiments entailed 6 rats per group and statistical comparisons were determined using the Mann Whitney U test.

SPSS -20 (IBM, US) statistical package was used for data analysis and $* 0.05$ and $* * 0.01$ was considered as indicative of significance as compared to the control group.

\section{Results}

Detection of endotoxin contamination of the MLCC

Adding the LAL regents to the MLCC did not result in a firm clot which was visible in the positive control of the text kit indicative of absence of the endotoxins.

\section{Effect of the MLCC on nonfunctional immunological parameters of rats \\ Enumeration of immune cells; platelet, white blood cell (WBC), bone marrow cell (BMC) and splenocyte (SC) counts of rats}

Compared with the control, platelet counts were significantly increased by 42,59 and $68 \%$ in rats treated with low, mid and high doses of the MLCC $(p<0.05)$, respectively (Fig. 1a). The mid and high doses of the MLCC significantly increased the total WBC by 15 and $19 \%(p<0.05)$, respectively (Fig. 1a). Similarly, BMC counts significantly increased by the mid $(25 \%)$ and high doses $(49 \%)(p<0.05)$ (Fig. 1a). Differential WBC count of the MLCC treated rats recorded a marked amelioration of monocyte and lymphocyte counts compared with the control $(p<0.05)$; Monocyte and lymphocyte counts were significantly increased by mid (43.23\%, $7.5 \%)$ and high $(44.67 \%, 10 \%)$ doses $(p<0.05)$, respectively, of the MLCC (Fig. 1b).

\section{Plasma cytokine levels}

The oral administration of the highest dose of the MLCC compared with the control significantly reduced pro inflammatory cytokines, TNF $\alpha$ (by 39.09\%) and IL-6 (by $55.06 \%)$ as depicted in Fig. $2(p<0.05)$. Although IFN $\gamma$ levels were also reduced in treated groups compared to controls, the reduction was not significant $(p>0.05)$ (Figure 2). Plasma levels of IL-10 of both control and treated rats were below the detection level of the ELISA kit used.

\section{Effect of the MLCC on functional immunological parameters of rats} Phagocytic activity of peritoneal macrophages (PM) of rats

The functional assay based on phagocytic activity was significantly and dose dependently $\left(r^{2}=0.99\right)$ increased in rats of all treated doses (low: by $43 \%$ mid: $79 \%$ and high: 109\%) compared with the rats of the control group $(p<0.05)$ (Figure 3).

\section{In vitro phagocytic activity of rat peritoneal macrophages (PMs)}

As represented in Fig. 4A the MLCC markedly enhanced in vitro phagocytic activity of rat PMs at MLCC concentrations of $62.5,125,250,500$ and $1000 \mu \mathrm{g} / \mathrm{ml}$ by 112.5 , $168.75,189.58,139.5$ and $72.91 \%$, respectively $(p<0.05)$. The exception was the lowest concentration of MLCC tested $(31.25 \mathrm{mg} / \mathrm{ml})$ that had no effect on the phagocytic activity of PMs.

\section{Cytokine profile of peritoneal macrophage (PM) culture}

Compared with the control, the MLCC at 62.5, 125, 250, 500 and $1000 \mu \mathrm{g} / \mathrm{ml}$ concentrations significantly enhanced both IFN $\gamma$ and IL-10 from cells in PM culture $(p<0.05)$ (Fig. 4b). However, the control and 31.25, $62.5,125$ and $250 \mu \mathrm{g} / \mathrm{ml}$ of MLCC exhibited a Th1 (T helper 1 ) biased cytokine response (Th1/Th2 > 1) while higher concentrations 500 and $1000 \mu \mathrm{g} / \mathrm{ml}$ concentrations exerted a Th2 biased response $(\mathrm{Th} 1 / \mathrm{Th} 2<1)$ (Fig. 4c).

\section{Ex vivo proliferation of rat $B M C s$ and $S C s$}

Compared with the control the MLCC at $31.25 \mu \mathrm{g} / \mathrm{ml}$ concentration significantly increased the proliferation of BMCs by $63.2 \%$ in the absence of mitogens $(p<0.01)$. Conversely, the MLCC at high concentrations of 500 and $1000 \mu \mathrm{g} / \mathrm{ml}$ exerted a significant cytotoxic effect with 36.76 and $37.09 \%$ cell inhibition of BMCs $(p<0.05)$, respectively (Fig. 5a).

Similarly, significant cell proliferation of 39.62 and $33.96 \%$ was observed in SC cultures treated with MLCC at 31.25 and $62.5 \mu \mathrm{g} / \mathrm{ml}$ concentrations, respectively $(P<0.01)$. Similar to that of the BMCs the highest tested concentrations of 500 and $1000 \mu \mathrm{g} / \mathrm{ml}$ manifested $17.82 \%$ and $19.08 \%$ cell inhibition respectively, indicative of significant cytotoxic activity $(p<0.05)$ (Fig. 5c).

The MLCC at 125 and $250 \mu \mathrm{g} / \mathrm{ml}$ concentrations had no significant effect on both BMC and SC and the cell viabilities were comparable to that of the control. 


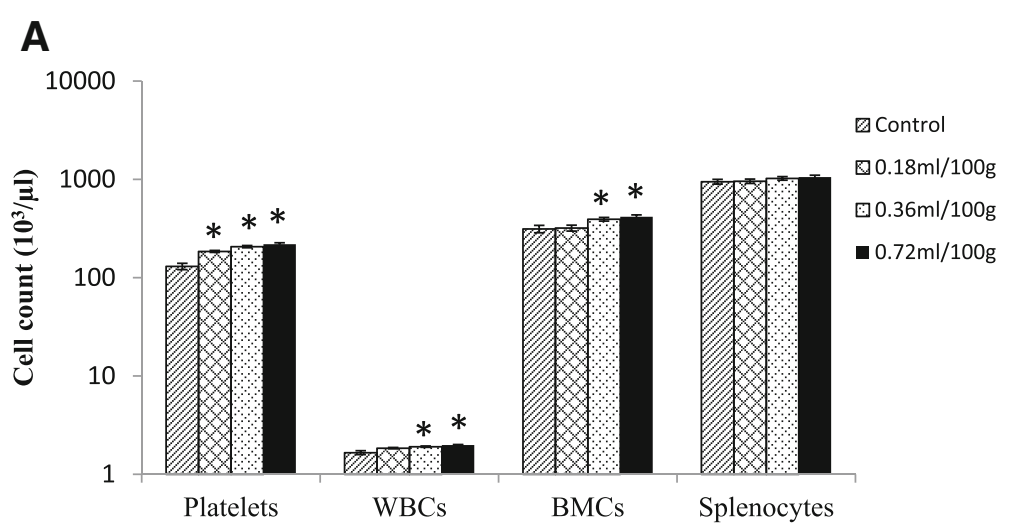

B

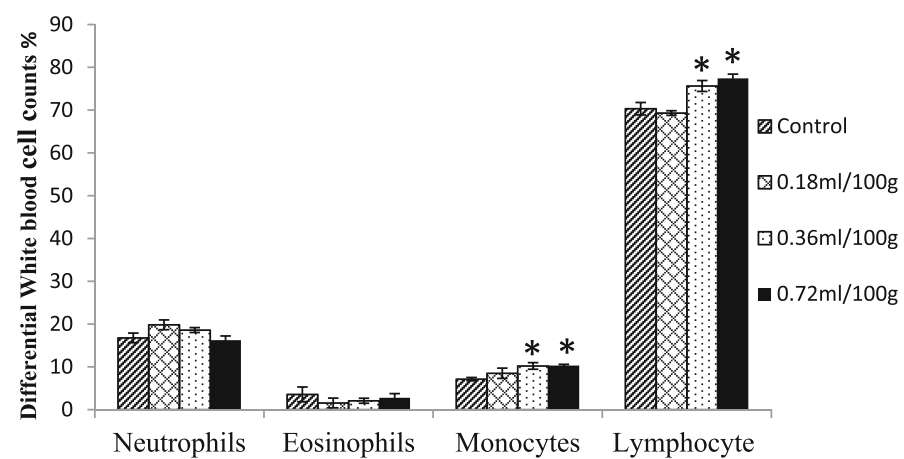

Fig. 1 Effect of the MLCC on a Enumeration of rat immune cells: platelets, total white blood cells, bone marrow cells, and splenocytes $\mathbf{b}$ Differential counts of rat peripheral leukocytes. Results are expressed as Mean \pm SEM for the number of animals used $(n=6) .{ }^{*} p<0.05$ were considered significant when compared with the control (Mann Whitney $U$ test)

LPS $(2 \mu \mathrm{g} / \mathrm{ml})$, a known mitogen, elicited a significant enhancement of both BMC (158.8\%) and SC (127.88\%) proliferation, respectively as presented in Figs. 5a, c $(p<0.01)$.

\section{Cytokine profile of rat BMC and SC culture supernatants}

IFNY (Th1 cytokine) levels of BMCs treated with MLCC with the exception of $31.25 \mu \mathrm{g} / \mathrm{ml}$ concentration were

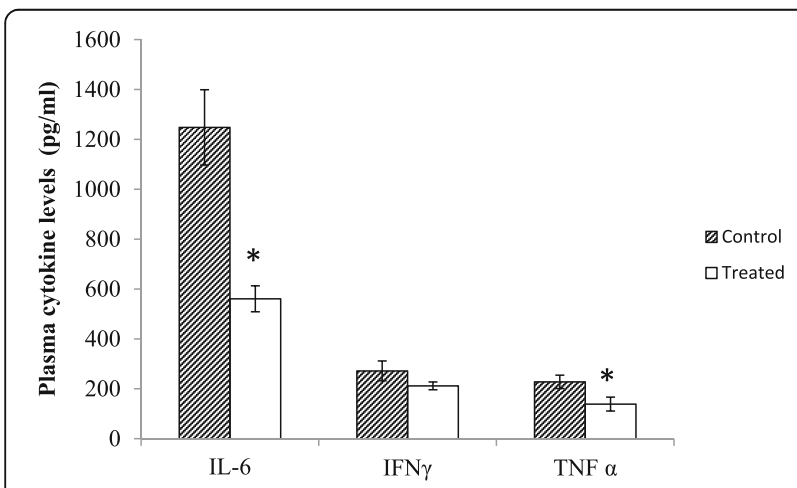

Fig. 2 Plasma cytokines - IFNY, TNFa, IL-6 and IL-10 levels of rats orally gavaged with the MLCC. Results are expressed as Mean \pm SEM for the number of animals used ( $n=6 /$ group). ${ }^{*} p<0.05$ were considered significant when compared with the control (Mann Whitney $U$ test) significantly higher compared to that of the control (Fig. 5b) $(p<0.05)$. However, IL-10 level of BMCs was only increased by the $62.5 \mu \mathrm{g} / \mathrm{ml}$ MLCC treatment $(p<0.05)$ (Fig. 5b).

All tested concentrations of the MLCC significantly stimulated the secretion of IFN $\gamma$ from the SCs compared

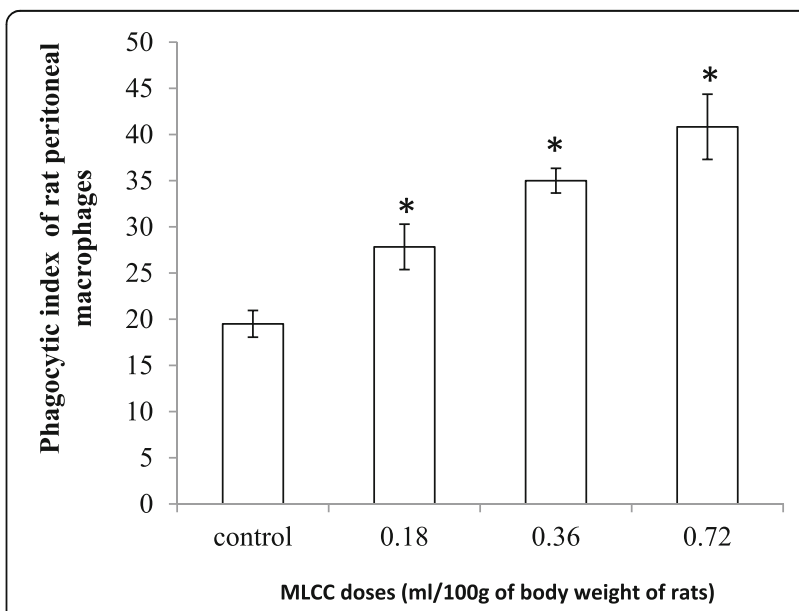

Fig. 3 Phagocytic activity of rat peritoneal macrophages following oral treatment of MLCC. Results are expressed as Mean \pm SEM for the number of animals used ( $n=6 /$ group). ${ }^{*} p<0.05$ were considered significant when compared with the control (Mann Whitney $U$ test) 

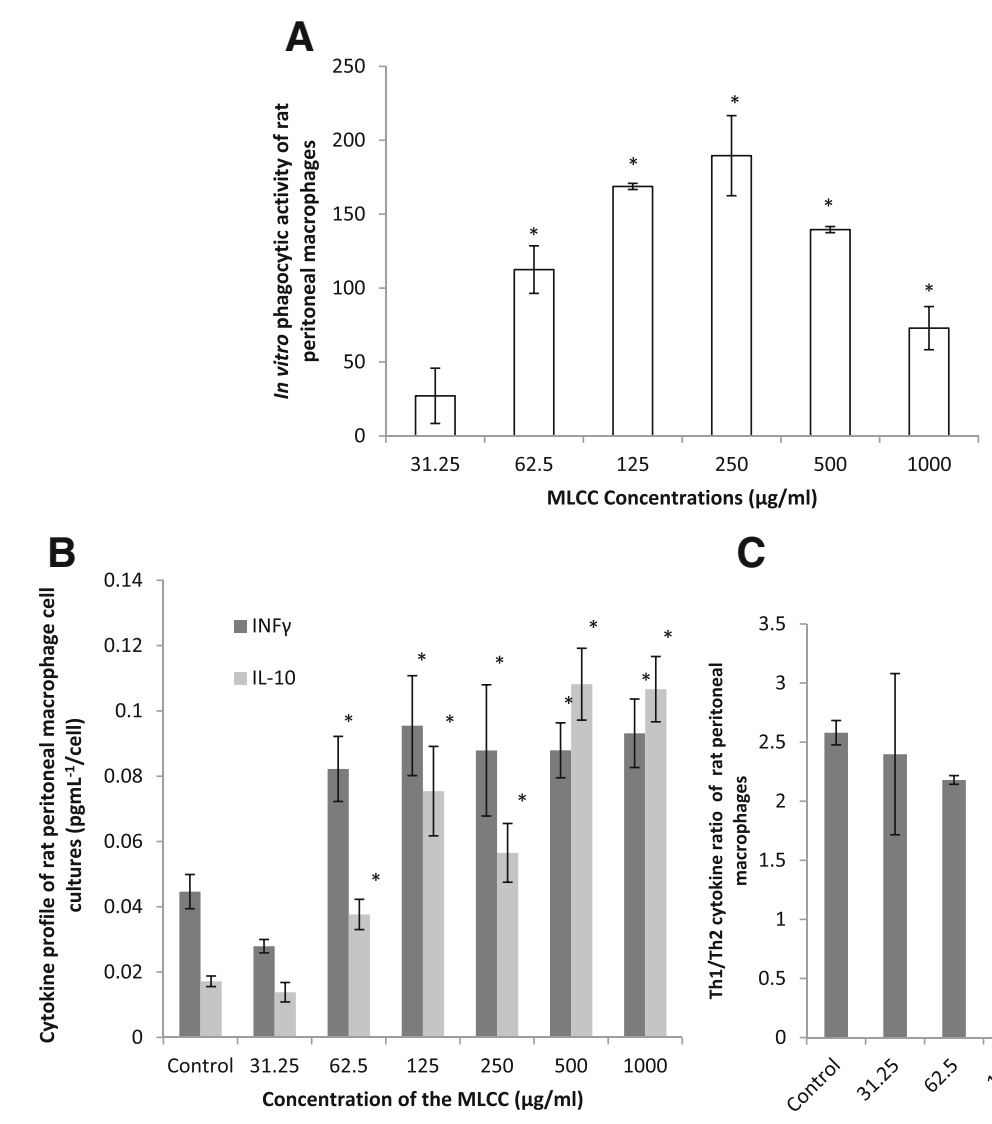

C

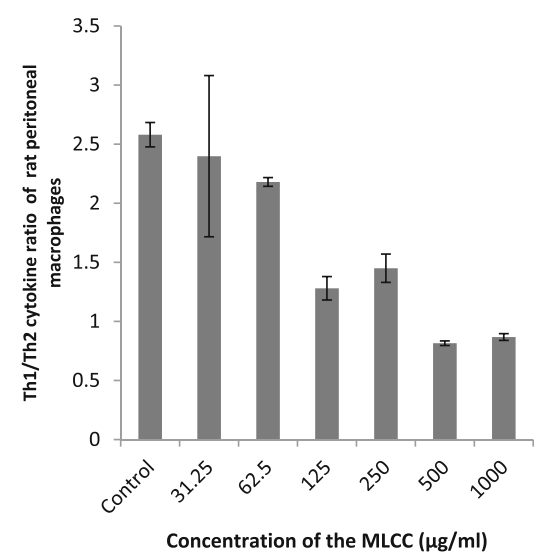

Fig. 4 Effect of the MLCC on a in vitro phagocytic activity of rat peritoneal macrophages, $\mathbf{b}$ the associated cytokine; IFNy and IL-10 profile. c Th1/Th2 bias cytokine response. Results are expressed as Mean \pm SEM. ${ }^{*} p<0.05$, ${ }^{* *} p<0.01$ were considered significant when compared with the control (ANOVA)

with the control $(p<0.05)$. Conversely, the MLCC at $31.25,62.5$ and 125,250 and $500 \mu \mathrm{g} / \mathrm{ml}$ concentrations significantly inhibited the secretion of IL-10 from SCs compared with the control $(p<0.05)$ (Fig. 5d). While SCs treated with $1000 \mu \mathrm{g} / \mathrm{ml}$ was comparable to that of the control $(p>0.05)$ (Fig. 5d).

The BMCs treated with LPS $(2 \mu \mathrm{g} / \mathrm{ml})$ significantly increased the IL-10 $(p<0.05)$ level while IFN $\gamma$ was comparable $(p>0.05)$ to that of the control. Conversely, SCs treated with LPS significantly elevated IFN $\gamma$ level and inhibited the IL-10 level compared to that of the control $(p<0.05)$ (Figs. 5b, d).

\section{Acute toxicity of the MLCC on rats}

Acute oral treatment of the highest dose $(0.72 \mathrm{ml} / 100 \mathrm{~g}$ $\mathrm{BW})$ of the MLCC elicited neither hepato nor renal toxicities. Serum levels of liver functional parameters (ALT and AST) were not significantly different in the treated group compared to the control $(p>0.05)$ (Fig. 6). Similarly, renal parameters (urea, BUN and creatinine) were unaltered in the test group compared to the control (Fig. 6).

\section{Chemical profile of the MLCC}

Figure 7 a represents the major peaks obtained for the MLCC from the PDA detector. Retention times and wavelengths of major peaks observed are summarised in Table 1.

The GC-MS chromatographic peaks are presented in Fig. $7 \mathrm{~b}$ and the identified compounds are lists in Table 2.

\section{Discussion}

The present study for the first time established, that the mature leaf concentrate of the Sri Lankan wild type cultivar of C. papaya modulates both nonfunctional and functional immune responses of Wistar rats.

The oral administration of MLCC for 3 consecutive days had significantly ameliorated rat immune cell counts i.e. platelets, WBC and BMCs, where platelet increasing activity was pronounced. Increase of both platelets and WBCs were consistent with previous studies established with non-thrombocytopenic [14, 15] as well as thrombocytopenic murine models $[12,13]$.

The immunostimulatory potential of the MLCC is well illustrated in the numerical increment of total WBCs as 


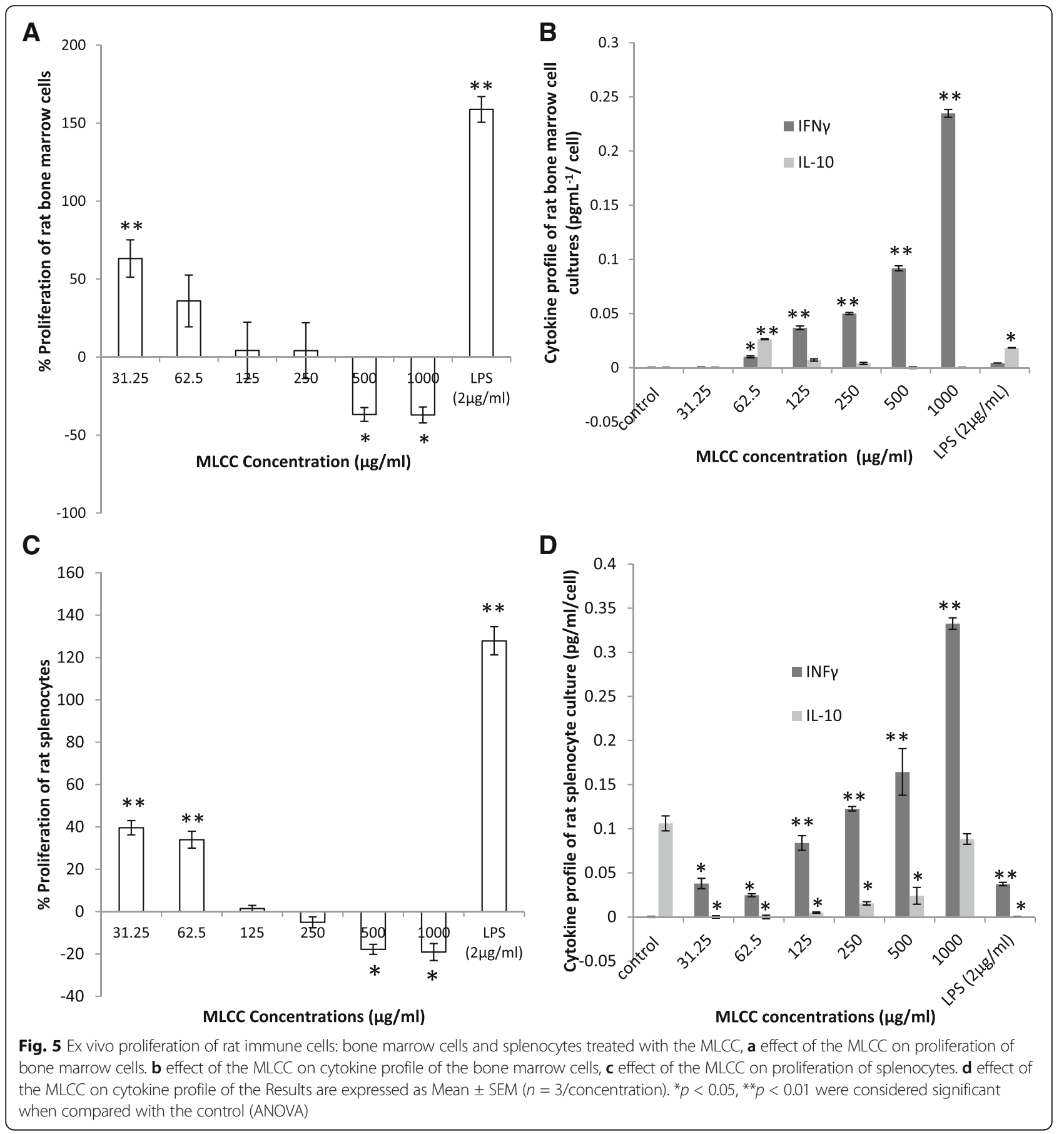

well as of sub populations of monocytes and lymphocytes. Significant increase in the percentage of circulating mononuclear cells (lymphocytes and monocytes) indicated the effectiveness of the MLCC on both innate and adaptive arms of the immune system [1]. Previously, aqueous leaf extract of $C$. papaya treated peripheral blood mononuclear cells (PBMCs) elicited an up regulation of 23 genes mainly including monocyte chemo-attractant protein-1, 2 and 3 (MCP-1, MCP-2 and MCP-3) [19].
These proteins regulate the migration and infiltration of monocytes/macrophage [27]. Thus, activation of monocytes in numbers and function by the papaya leaf constituents raise the possibility of enhancing immunological surveillance.

The mechanism of the papaya leaf constituents induced platelet and leukocyte increment continues to be explored. Augmentation of bone marrow hematopoiesis is the most debated mechanism in literature [28]. Tham et 


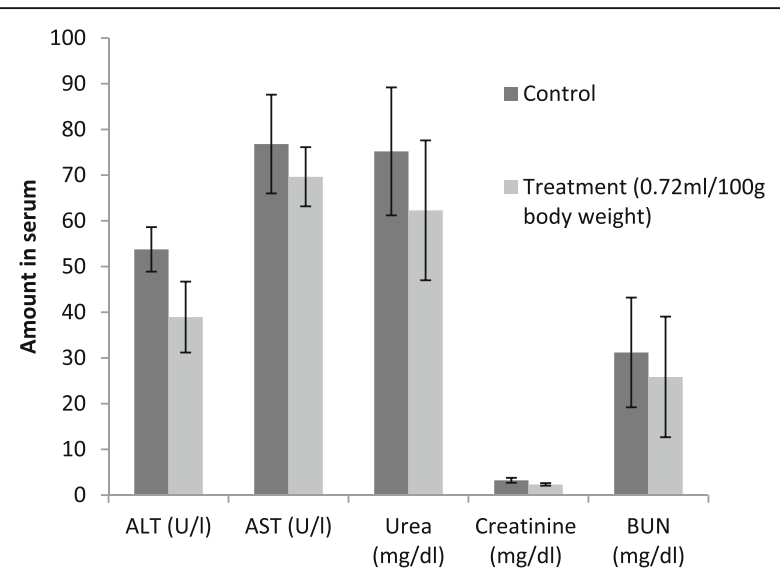

Fig. 6 Effect of the oral administration of the MLCC on hepato (AST,ALT) and renal parameters (urea, BUN and creatinine) of rats. Results are expressed as Mean \pm SEM for the number of animals used ( $n=6 /$ group). ${ }^{*} p<0.05$ were considered significant when compared with the control (Mann Whitney $U$ test)

al., [29] established that the leaf extract of C. papaya can reverse lead acetate induced oxidative damage by regeneration and stimulation of hematopoiesis, particularly of myeloblasts and megakaryocytes as evident in histopatholoigcal examination [29]. Moreover, the unaltered levels of SC counts which are mature lymphocytes also highlight the preference of the MLCC on hematopoietic stem cells. Therefore, it may be posited that the MLCC specifically stimulates hematopoietic stem cells to propagate and differentiate into precursor cells of megakaryocytes and those of leukocyte origin which will be mobilized in peripheral blood. In addition to the stimulation of BMCs, a rapid elevation of platelets in thrombocytopenic rats following oral gavage of MLCC was surmised to the release of stored platelets from the spleen [11]. An observation of platelet increment by the low dose of MLCC irrespective of significant upsurge of BMCs agrees with the probable release of stored platelets in the spleen.

Previously, upregulated synthesis of IL-6, a major thrombopoietic cytokine, was observed in human peripheral blood lymphocytes and stem cells from exfoliated deciduous teeth following the treatment with unripe papaya extract rich in papain [30]. This finding prompted us to investigate the effects of the oral gavage of MLCC on rat cytokine levels which may regulate the immune responses.

The present study established, in contrast to Aziz et al. [30], that plasma levels of IL-6 were significantly reduced in rats treated with the MLCC. Although, papaya based extracts are known to induce IL-6 levels in in vitro stem cell cultures, oral administration of the MLCC had reduced the systemic IL- 6 levels. This paradox may be due to different experimental systems and pleiotropic activity of IL-6 [31].
Similar to that of IL-6, TNF $\alpha$ levels were significantly reduced by the oral treatment of MLCC. Conversely, the reduction of IFN $\gamma$ levels was not significant. Since, IL-10 levels were lower than the detection levels of the ELISA kits used, the influence of MLCC on IL-10 cannot be predicted. However, inhibition of TNF $\alpha$ indicated antiinflammatory property of the MLCC which was established previously $[11,32]$.

The MLCC, administered orally to rats enhanced phagocytosis of peritoneal macrophages and suggested a modulation of functional immunity of rats. Consistent with our findings, Tomar et al. [21] in 2012 demonstrated that oral treatment of an alcohol extract of $C$. papaya leaf significantly increased carbon clearance by the rat reticular-endothelial system that provided evidence for enhanced phagocytosis [21].

The in vitro phagocytic activity based on NBT dye reduction assay, revealed an enhancement of phagocytosis by the MLCC treatment. However, precise dose dependency was not observed. Increased phagocytosis in both in vitro and in vivo experiments signifies the immunostimulatory potential of the MLCC.

Increased phagocytic activity of the PMs was correlated with Th1 type cytokine response. IFN $\gamma$ enhances phagocytosis and increases protection towards pathogens [33]. The MLCC mediated IL-10 may stimulate the anti-inflammatory responses [34] and may lessen the consequences of inflammation.

The functional immunological assays based on ex vivo proliferation provide more concrete evidence for immunomodulatory potential of the MLCC. The proliferation ability of the MLCC was compared with LPS, a bacterial endotoxin that revealed paradoxical activity i.e. low concentrations of the MLCC stimulated the proliferation while higher concentrations exhibited cytotoxic activity. Such a biphasic dose responsive effect is termed "hormesis" [35]; A comparable response pattern was observed in in vitro membrane stabilization potential of papaya leaf extract [36]. Thus, we assume bioactivities of the papaya leaf constituents may follow this type of dose response.

The significant proliferation of BMCs and SCs by the low concentration of the MLCC may be attributed to the presence of single or several types of mitogens or growth factors. Plant mitogens such as lectins are glycoproteins that nonspecifically bind to cell surfaces and stimulate cells to undergo mitosis [37]. However, these are selective in triggering $\mathrm{T}$ or $\mathrm{B}$ cell populations. Previously, several mitogens such as Phytohaemagglutinin(PHA), concanavalin A (Con A) and Pokeween Mitogen (PWM) have been identified from plants and these mostly impacted on the proliferation of $\mathrm{T}$ lymphocytes [37].Conversely, polysaccharides, polyneucleotides or lipoproteins from bacterial cell wall favor B cell proliferation. There is a high possibility that fresh plant extracts 


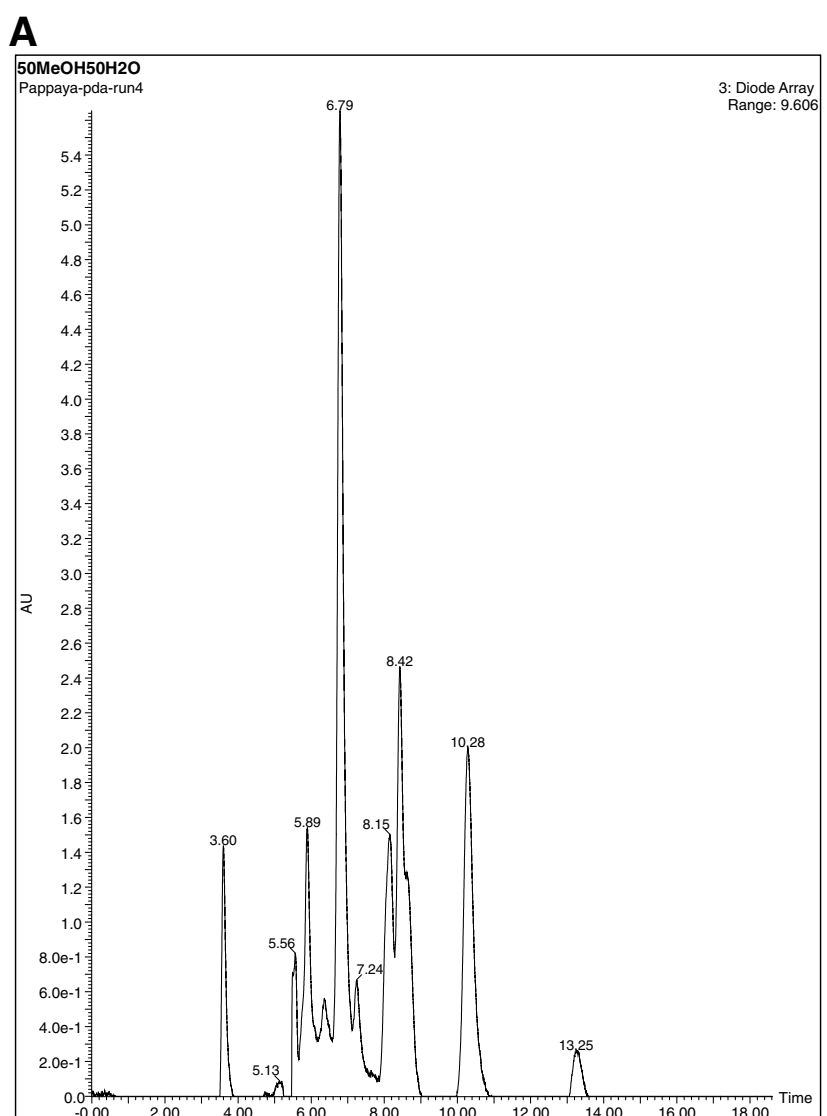

B

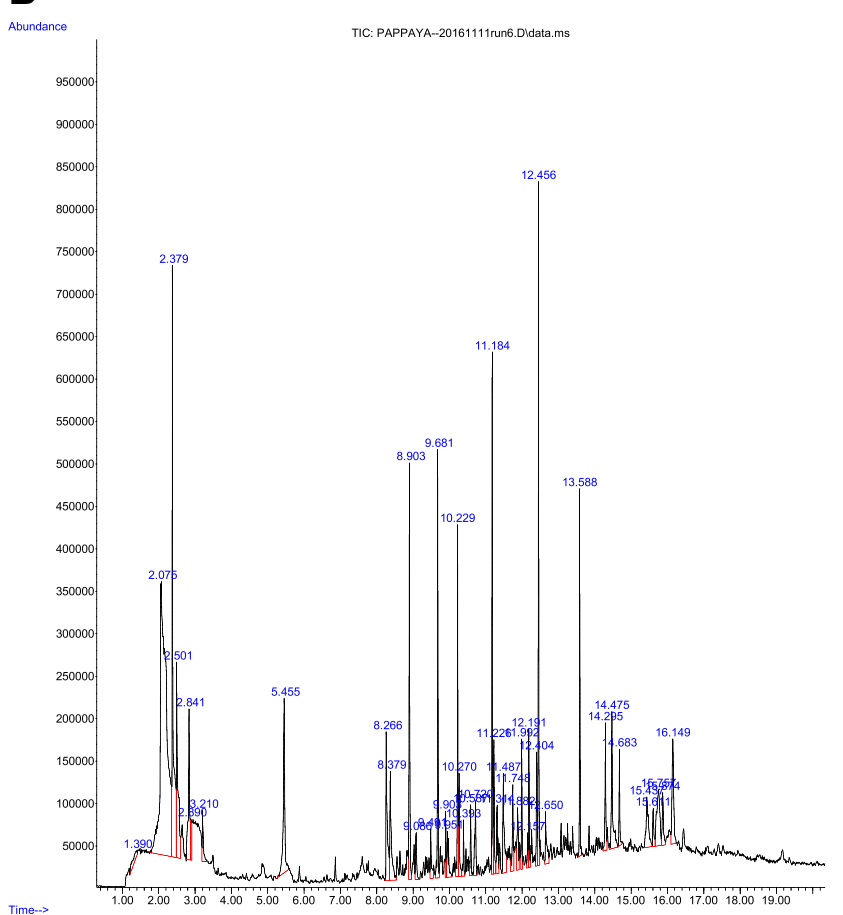

Fig. 7 Chemical Profiling of the MLCC. a LC-MS chromatogram, b GC-MS chromatogram of the MLCC. Molecular weights, peak retention times and wave length of the peaks are given 
Table 1 Retention times and the wavelengths of the compounds of the MLCC detected by the LC-MS

\begin{tabular}{ll}
\hline Peak Retention time $(\mathrm{min})$ & Wave length $(\mathrm{nm})$ \\
\hline 3.60 & 489 \\
5.13 & 252 \\
5.56 & 263 \\
5.89 & 280 \\
6.35 & 280 \\
6.79 & 328 \\
7.24 & 245 \\
8.15 & 314 \\
8.42 & 316 \\
10.28 & 343 \\
13.25 & 258 \\
\hline
\end{tabular}

such as the MLCC may contain bacteria and their products (endotoxins) which may provide false positive results. To eliminate such contaminations the MLCC was filtered using $0.22 \mu \mathrm{m}$ filter and furthermore, contamination of bacterial endotoxins was ruled out due to negative results obtained from the LAL test, confirming that the mitogenic activity indeed resulted due to phytoconstituents of the MLCC.

Previously, human PBMC cultures treated with $C$. papaya aqueous leaf extract revealed an enhanced production of cytokines, such as IL-12p40, IL-12p70, IFN- $\gamma$ and TNF- $\alpha$ without growth inhibition [19]. A similar pattern of IFNy release was observed in both rat cell types (BM and SC) we tested, but in contrast to Ostuski et al. [19] we observed significant cell inhibition at high concentrations (500 and $1000 \mu \mathrm{g} / \mathrm{ml}$ ) of the MLCC. This disparity may be due to different types of preparation of the papaya leaf, different papaya cultivars used, and cell types used in these two studies.

IFN $\gamma$ has been specifically reported as a hematopoietic inhibitor as it attenuates human bone marrow colony formation and inhibits CD34+ bone marrow cells [38]. Thus, IFN $\gamma$ may have played a major role in the cell inhibition observed in high concentrations of the MLCC (500 and $1000 \mu \mathrm{g} / \mathrm{ml}$ ). Similarly, elevated level of IFNY was observed in SCs upon treatment with the MLCC and higher IFN $\gamma$ levels were correlated with the inhibition of SCs counts. Thus, MLCC induced higher IFNY may contribute to the inhibition of both BMCs and SCs under in vitro conditions.

Both in vivo and in vitro murine models verified the remarkable immunomodulatory potential of the MLCC. In vivo immunomodulation indicated that the active constituents of the MLCC are indeed bioavailable and effective against the ethno -pharmacologically accepted oral route [39].
Table 2 Chemical compounds of the MLCC identified from GC-MS

\begin{tabular}{|c|c|c|c|}
\hline No & $t_{R}$ & $m / z$ & Assignment \\
\hline 1 & 1.390 & $260.9,202.1,157.1,103.9,63.2$ & Bis (2-(2-chloroethoxy)ethyl) ether \\
\hline 2 & 2.075 & $369.9,338,105.1,75$ & Dimethoxydimethylsilane \\
\hline 3 & 2.379 & $280.9,241,207.2,91,61$ & $\begin{array}{l}\text { 3-Benzoyl-8-oxo-6-azabicyclo[3.2.1] } \\
\text { octan-6,7-dicarboxylicacid, dibenzyl } \\
\text { ester }\end{array}$ \\
\hline 4 & 2.501 & $281,265,105,91,77$ & Benzhydrazide \\
\hline 5 & 2.841 & $233.1,206.9,87.1,61$ & o-Butylisourea \\
\hline 6 & 2.890 & $267.1,210,193,87.1,55.1$ & $\begin{array}{l}\text { 10-Oxatetracyclo[5.5.2.0(1,5).0(8,12)] } \\
\text { tetradecene-9,11,14-trione, } \\
\text { 4-[(2-methoxyethoxy)methoxyl]- } \\
\text { 5-methyl- }\end{array}$ \\
\hline 7 & 3.210 & $206.8,190.9,107,91.1,77$ & $\begin{array}{l}\text { 2-chloro-5,5-dimethyl-1-phenyl-3- } \\
\text { hexen-1-ol }\end{array}$ \\
\hline 8 & 5.455 & $207,179,163,119$ & 2-methoxybenzeneacetaldehyde \\
\hline 9 & 8.266 & & 1-methyl-2-pyrrolidinone \\
\hline 10 & 8.379 & $280.9,253.1,223$ & Benzonitrile \\
\hline 11 & 8.903 & $206.9,142.1,98.1,82.1$ & Nonanal \\
\hline 12 & 9.086 & $355.1,281.1,207,119.1$ & Octanoic acid, methyl ester \\
\hline 13 & 9.491 & $355.9,207.1,119.1$ & Octanoic acid \\
\hline 14 & 9.681 & $280.8,208,168.1,128$ & 1-Decene \\
\hline 15 & 9.903 & $281.1,266.8,207,120.1$ & n-benzyl-n-phenylethylisobutyramide \\
\hline 16 & 9.951 & $370.8,280.9,207,74.1$ & Nonanoic acid, methyl ester \\
\hline 17 & 10.229 & $207,190.2,175.1,91$ & Benzene, 1,3-bis(1,1-dimethylethyl)- \\
\hline 18 & 10.270 & $206.8,181,158.2,73.1$ & Nonanoic acid \\
\hline 19 & 10.393 & $206.9,169.1,148,85.1,71.1$ & 1-lodooctadecane \\
\hline 20 & 10.587 & $206.9,167.9,155.1,142.1$ & 2-Methylnaphthalene \\
\hline 21 & 10.720 & $429.1,341,281.1,207$ & 2-Methylnaphthalene \\
\hline 22 & 11.184 & $401.1,354.9,267.1,196.2$ & 2-Tetradecene \\
\hline 23 & 11.226 & $355,326.8,297,144, .1$ & 10-Undecenoic acid, methyl ester \\
\hline 24 & 11.314 & $207.1,189,152,82$ & Dodecanal \\
\hline 25 & 11.487 & $280.9,207,192.1,156$ & 1,4-dimethylnaphthalene \\
\hline 26 & 11.748 & $327.1,281,206.9,144.1$ & 9-Oxononanoic acid \\
\hline 27 & 11.882 & $207,168.1,141,113.2$ & 1-Hentriacontane \\
\hline 28 & 11.992 & $280.9,206.1,191.2,175.1$ & 2,4-Di-tert-butylphenol \\
\hline 29 & 12.157 & $291.2,207.1,182.2,155$ & 1-lodooctadecane \\
\hline 30 & 12.191 & $280.9,207.1,185.1,152$ & Nonanedioic acid, dimethyl ester \\
\hline 31 & 12.404 & $283.1,252.9,207.1,152.1$ & Azelaic acid \\
\hline 32 & 12.456 & $280.9,224.2,196.2,97.1$ & 2-Tetradecene \\
\hline 33 & 12.650 & $355,281.2,207.1,152.1$ & Azelaic acid \\
\hline 34 & 13.588 & $281,252.2,224.1,97.1$ & 1-Octadecene \\
\hline 35 & 14.295 & $355.2,326.8,270.2,227.1$ & 1-Hexadecanoic acid \\
\hline 36 & 14.475 & $405.2,355,328,256.3$ & n- Hexadecanoic acid \\
\hline 37 & 14.683 & $405,355.1,327.1,280.9$ & Cycloeicosane \\
\hline 38 & 15.437 & $405.1,355,331,281$ & $\begin{array}{l}\text { 9-Octadecenoic acid, methyl } \\
\text { ester }\end{array}$ \\
\hline 39 & 15.611 & $355,327,298.3,281$ & Methyl Stearate \\
\hline 40 & 15.757 & $405.1,355,326.9,294.2$ & $\begin{array}{l}\text { Methyl 2-octylcyclopropene-1- } \\
\text { heptanoate }\end{array}$ \\
\hline 41 & 16.148 & $429.1405 .1,355.2,294.1$ & 9,12-Octadecadienoic acid \\
\hline
\end{tabular}

The ethno - pharmacological significance of the MLCC was further emphasized by its safety. Though, the MLCC exerted in vitro cytotoxicity at higher 
concentrations against cultured cells it was well tolerated by rats showing no overt signs of toxicity, stress, aversive behavior or behavioral changes. Further, hepato and renal toxicity were also ruled out. Also, the MLCC failed to alter the body weights and the weights of vital organs of the test rats.

The chemical profile data obtained from LC-MS and GC-MS chromatograms revealed the presence of several bioactive compounds. The LC-MS profile exhibited several peaks and it is presumed these peaks resemble both mitogenic and anti-inflammatory compounds. Among them phenolics and flavonoids may be prominent as previous studies reported phenolic and flavonoids were abundant in the papaya leaf [40]. Further, studies are required to identify the compounds obtained from the LC-MS analysis.

Several potent anti-inflammatory compounds such as Azelaic acid [41], 1-Hexadecanoic acid [42], antioxidant compounds; 2,4-Di-tert-butylphenol [43], were elucidated in the GC-MS analysis. Hence, reported immunomodulatory properties of the MLCC could be attributed to these compounds. In addition, the GC-MS profile revealed the presence of several cytotoxic compounds such as 9-Octadecenoic acid methyl ester [44], 2,4-Di-tert-butylphenol [43] and Benzhydrazide [45]. Thus, these compounds may have contributed to the MLCC induced cytotoxicity observed in higher MLCC concetrations in in vitro cultures of $\mathrm{PM}, \mathrm{BMC}$ and SCs and warrant the investigation of anticancer activity of the MLCC.

The remarkable ability of differential modulation of the immune system was previously reported for a few plants such as Echinacea angustifolia and Pelargonium sidoides Echinacea [39]. However some preparations are active only in in vitro systems. Nevertheless, the MLCC is an orally active, safe, and readily available preparation which has the potential to develop a therapeutic lead, with immense benefit to individuals suffering from immune disorders such as infections, autoimmune diseases and cancers.

\section{Conclusion}

The present study in toto established that the MLCC effectively modulates the nonfunctional and functional immune responses such as stimulation of immune cell proliferation, increase of phagocytosis activity and modulates cytokine responses. Several active secondary metabolites with immunomodulatory properties were identified.

Collectively, when administered orally, the MLCC is safe (non-toxic) for a period of 3 days and is orally active, effectively modulates the immune response and inhibits pro-inflammatory cytokines which overly justify claims of traditional medicine. Hence, the MLCC may be a potential candidate for further research leading to the development of a herbal therapeutic agent for modulating the immune system in numerous diseases.

\section{Abbreviations}

ALOX-12: Arachidonate 12-Lipoxygenase; ALT: Alanine transaminase; AST: Aspartate transaminase; BALB: Bagg Albino laboratory bred; BMC: Bone marrow cells; BUN: Blood urea nitrogen; BW: Body weight; Con A: Concanavalin A; COX: Cyclooxygenases; CRPMI 1640: Complete Roswell Park Memorial Institute; DF: Dengue fever; DHF: Dengue haemorrhagic fever; DMSO: Dimethyl sulfoxide; DW: Distilled water; EDTA: Ethylenediaminetetraacetic acid; ELISA: Enzyme Linked Immunosorbent Assay; FBS: Fetal bovine serum; GC-MS: Gaschromatography- mass spectroscopy; HA: haemagglutination antibody; $\mathrm{HCl}$ : Hydrochloride acid; IFNY: Interferon gamma; IL-10: Interleukin 10; IL6: Interleukin 6; $\mathrm{KOH}$ : Pottasium hydroxide; LAL: Limulus amebocyte lysate; LC-MS: Liquid chromatography- mass spectroscopy; LOX: Lipooxygenases; LPS: Lipopolysaccharides; MAPKs: Mitogen-activated protein kinases; MCH: Mean cell haemoglobin; MCP: Monocyte chemo-attractant protein; MCV: Mean corpuscular volume; MLCC: Mature leaf concentrate of Carica papaya; MSD: Mass Selective Detector; MTT: 4,5-dimethylthiazole-2-yl)-2,5-diphenyltetrazolium bromide; NBT: Nitrobluetetrazolium, NIST- National Institute of standards and Technology (NIST); OECD: Organization for Economic Co-operation and Development; PBMC: Peripheral blood mononuclear cells; PBS: Phosphate Buffered Saline; PDA: photodiode array; PHA: Phytohaemagglutinin; PMs: Peritoneal macrophages; PWM: Pokeween Mitogen; RPMI 1640: Roswell Park Memorial Institute 1640; SC: Splenocytes; SEM: Standard error of means; Th cells: T helper cells; TNF a: Tumor Necrosis Factor a; WBC: white blood cells

\section{Acknowledgement}

Financial assistance by the Collaborative Research Grant (AP/3/2012/CG/29) of the University of Colombo, Sri Lanka. Sri Lanka Institute of Nanotechnology, Mahenwatte, Pitipana, Homagama, Sri Lanka is acknowledged for providing facilities for chemical analysis of the MLCC.

\section{Funding}

Financial assistance by the Collaborative Research Grant (AP/3/2012/CG/29) of the University of Colombo, Sri Lanka.

\section{Availability of data and materials}

The supporting materials can be obtained upon request via email to the corresponding author

\section{Authors' contributions}

PVU and CDJ contributed towards the conception, analysis, and manuscript writing. CDJ and KKMJ conducted the laboratory experiments. DSG and NDS conducted the LC-MS and GC-MS analyses of the MLCC and data interpretation. PVU made contributions to acquisition of data, interpretation of data and intellectual content. All authors read and approved the final manuscript.

\section{Authors' information}

PVU, a Professor in Zoology at the University of Colombo, Sri Lanka, obtained her $\mathrm{PhD}$ in Immuno-parasitology from the Faculty of Medicine, University of Colombo. She was awarded with visiting \& postdoctoral fellowships from NSERC, Canada. PVU has many peer reviewed journal publications and is currently supervising a research project on "Hematological, anti-inflammatory potential and toxicity of mature leaf concentrate of Carica papaya" (AP/3/2012/CG/29).

CDJ obtained an MSc in Epigenetics from the University of Osaka, Japan and is a Senior Lecturer at the Open University of Sri Lanka. She is currently reading for her $\mathrm{PhD}$ at the department of Zoology and Environment Sciences, University of Colombo. CDJ is the research assistant of the research project "Hematological, anti-inflammatory potential and toxicity of mature leaf concentrate of Carica papaya" (AP/3/2012/CG/29).

DSG is Senior Research Scientist at SLINTEC and obtained MSC (Organic Chemistry) from University of Minnesota, USA and PhD from University of Purdue, USA.

NDS is a Research Scientist at SLINTEC (Material Chemistry).NDS obtained his PhD from the University of Mississippi State University, USA. KKMJ was an undergraduate at the Department of Biotechnology, Faculty of Agriculture \& Plantation Management, Wayamba University of Sri Lanka.

\section{Competing interests}

The authors declare that they have no competing interests. 


\section{Ethics approval}

Ethical approval for the laboratory animal study was obtained from the Institute of Biology, Sri Lanka (Ethical approval number -IOBSL 11105 29). Hence, all experiments conducted were in compliance with the Organization for Economic Co-operation and Development (OECD) guidelines.

\section{Publisher's Note}

Springer Nature remains neutral with regard to jurisdictional claims in published maps and institutional affiliations.

\section{Author details}

'Department of Zoology \& Environment Sciences, Faculty of Science, University of Colombo, Colombo 3, Sri Lanka. ${ }^{2}$ Sri Lanka Institute of Nanotechnology, Mahenwatte, Pitipana, Homagama, Sri Lanka. ${ }^{3}$ Department of Biotechnology, Faculty of Agriculture \& Plantation Management, Wayamba University of Sri Lanka, Wayamba, Sri Lanka.

Received: 11 June 2016 Accepted: 13 April 2017

Published online: 26 April 2017

\section{References}

1. Janeway CA, Medzhitov R. Innate immune recognition. Annu Rev Immunol. 2002;20:197-216

2. Haddad PS, Azar GA, Groom S, Boivin M. Natural health products, modulation of immune function and prevention of chronic diseases. Evid Based Complement Alternat Med. 2005:2:513-20.

3. Aggarwal BB, Shishodia S, Sandur SK, Pandey MK, Sethi G. Inflammation and cancer: how hot is the link? Biochem Pharmacol. 2006;72:1605-21.

4. Mackay IR. Science, medicine, and the future: Tolerance and autoimmunity. BMJ. 2000:321:93-6.

5. de Souza AP, Bonorino C. Tumor immunosuppressive environment: effects on tumor-specific and nontumor antigen immune responses. Expert Rev Anticancer Ther. 2009:9:1317-32.

6. Orlicka K, Barnes E, Culver EL. Prevention of infection caused by immunosuppressive drugs in gastroenterology. Ther Adv Chronic Dis. 2013:4:167-85.

7. Sitzia J, Huggins L. Side effects of cyclophosphamide, methotrexate, and 5fluorouracil (CMF) chemotherapy for breast cancer. Cancer Pract. 1998;6:13-21.

8. Spelman K, Burns J, Nichols D, Winters N, Ottersberg S, Tenborg M. Modulation of cytokine expression by traditional medicines: a review of herbal immunomodulators. Altern Med Rev. 2006;11:128-50.

9. Mahima RA, Deb R, Latheef SK, Abdul Samad H, Tiwari R, Verma AK, Kumar A, Dhama K. Immunomodulatory and therapeutic potentials of herbal, traditional/indigenous and ethnoveterinary medicines. Pak J Biol Sci PJBS. 2012;15:754-74.

10. Vij T, Prashar Y. A review on medicinal properties of Carica papaya Linn. Asian Pac J Trop Dis. 2015:5:1-6.

11. Gammulle A, Ratnasooriya W, Jayakody J, Fernando C, Kanatiwela C, Udagama PV. Thrombocytosis and Anti-inflammatory Properties, and Toxicological Evaluation of Carica papaya Mature Leaf Concentrate in a Murine Model. Online Int J Med Plant Res. 2012;1:21-30.

12. Patil S, Shetty S, Bhide R, Narayanan S. Evaluation of platelet augmentation activity of Carica papaya leaf aqueous extract in rats. J Pharmacogn Phytochem. 2013;1:57-60

13. Arollado EC, Peňa IG, Dahilig VRA. Platelet Augmentation Activity of Selected Philippine Plants. Int J Pharm Phytopharm Res. 2013:3:121-3.

14. Dharmarathna SLCA, Wickramasinghe S, Waduge RN, Rajapakse RPVJ, Kularatne SAM. Does Carica papaya leaf-extract increase the platelet count? An experimental study in a murine model. Asian Pac J Trop Biomed. 2013;3:720-4.

15. Sheikh N, Younas N, Akhtar T. Effect of Carica papaya leaf formulation on hematology and serology of normal rat. Biologia (Pakistan). 2014;60(1):139-142.

16. Subenthiran S, Choon TC, Cheong KC, Thayan R, Teck MB, Muniandy PK, Afzan A, Abdullah NR, Ismail Z. "Carica papaya Leaves Juice Significantly Accelerates the Rate of Increase in Platelet Count among Patients with Dengue Fever and Dengue Haemorrhagic Fever," Evid Based Complement Alternat Med. 2013. Article ID 616737. doi:10.1155/2013/616737

17. Hettige S. Salutary effects of Carica papaya leaf extract in dengue fever patients - a pilot study. Sri Lankan Family Physician. 2008:29:17-19

18. Gowda A.C., Kumar N.V, Kasture P.N., Nagabhushan KH: A Pilot Study to Evaluate the Effectiveness of Carica papaya Leaf Extract in Increasing the Platelet Count in Cases of Dengue with Thrombocytopenia. Ind Med Gaz 2015:109-116.
19. Otsuki N, Dang NH, Kumagai E, Kondo A, Iwata S, Morimoto C. Aqueous extract of Carica papaya leaves exhibits anti-tumor activity and immunomodulatory effects. J Ethnopharmacol. 2010;127:760-7.

20. Strober W. Trypan blue exclusion test of cell viability. Current protocols in immunology. 2001. A3-B. doi:10.1002/0471142735.

21. Tomar SK, Thakur N, Kamaljeet. Immunostimulatory potential of an alcoholic extract (ACP) from Carica papaya against SRBC in Balb/C mice. Int J Phytopharm. 2012;3:194-7.

22. Hudson L, Hay FC. Practical immunology. 3rd ed. Oxford: Blackwell Scientific Publications; 1989.

23. Manosroi A, Saraphanchotiwitthaya A, Manosroi J. In vitro immunomodulatory effect of Pouteria cambodiana (Pierre ex Dubard) Baehni extract. J Ethnopharmacol. 2005;101:90-4.

24. Manosroi A, Saraphanchotiwitthaya A, Manosroi J. Immunomodulatory activities of Clausena excavata Burm. f. wood extracts. J Ethnopharmacol. 2003;89:155-60.

25. Mosmann T. Rapid colorimetric assay for cellular growth and survival: application to proliferation and cytotoxicity assays. J Immunol Methods. 1983;65:55-63

26. Jayasinghe CD, Udagama PV, Ratnasooriya WD. In-vivo antimalarial activity of aqueous root extract of Barringtonia acutangula in mice. Pharmacogn Mag. 2008;4(15(Suppl)):S1-7.

27. Deshmane SL, Kremlev S, Amini S, Sawaya BE. Monocyte chemoattractant protein-1 (MCP-1): an overview. J Interf Cytokine Res. 2009;29:313-26.

28. Ahmad N, Fazal H, Ayaz M, Abbasi BH, Mohammad I, Fazal L. Dengue fever treatment with Carica papaya leaves extracts. Asian Pac J Trop Biomed. 2011;1:330-3.

29. Tham CS, Chakravarthi S, Haleagrahara N, DE Alwis R. Morphological study of bone marrow to assess the effects of lead acetate on haemopoiesis and aplasia and the ameliorating role of Carica papaya extract. Exp Ther Med. 2013;5:648-52.

30. Aziz J, Abu Kassim NL, Abu Kasim NH, Haque N, Rahman MT. Carica papaya induces in vitro thrombopoietic cytokines secretion by mesenchymal stem cells and haematopoietic cells. BMC Complement Altern Med. 2015;15:215.

31. Kishimoto T. Interleukin-6: discovery of a pleiotropic cytokine. Arthritis Res Ther. 2006;8(Suppl 2):S2

32. Owoyele BV, Adebukola OM, Funmilayo AA, Soladoye AO. Anti-inflammatory activities of ethanolic extract of Carica papaya leaves. Inflammopharmacology. 2008:16:168-73.

33. Schroder K, Hertzog PJ, Ravasi T, Hume DA. Interferon-gamma: an overview of signals, mechanisms and functions. J Leukoc Biol. 2004;75:163-89.

34. Romagnani S, Kapsenberg M, Radbruch A, Adorini L. Th1 and Th2 cells. Curr Opin Hematol. 2001;149:871-3.

35. Calabrese EJ, Baldwin LA. Hormesis: the dose-response revolution. Annu Rev Pharmacol Toxicol. 2003:43:175-97.

36. Ranasinghe $P$, Ranasinghe $P$, Abeysekera WPKM, Premakumara GAS, Perera YS, Gurugama P, Gunatilake SB. In vitro erythrocyte membrane stabilization properties of Carica papaya L. leaf extracts. Pharm Res. 2012:4:196-202.

37. Yeap SK, Rahman MBA, Alitheen NB, Ho WY, Omar AR, Beh BK, Ky H. Evaluation of Immunomodulatory Effect: Selection of the Correct Targets for Immunostimulation Study. Am J Immunol. 2011;7:17-23.

38. Baldridge MT, King KY, Goodell MA. Inflammatory signals regulate hematopoietic stem cells. Trends Immunol. 2011;32:57-65.

39. Gertsch J, Viveros-Paredes JM, Taylor P. Plant immunostimulants-scientific paradigm or myth? J Ethnopharmacol. 2011;136:385-91.

40. Akhila S, Vijayalakshimi NG. Phytochemical studies on Carica papaya leaf juice. Int J Pharm Sci Res. 2015:6:880-3.

41. Sieber MA, Hegel JKE. Azelaic Acid: Properties and Mode of Action. Skin Pharmacol Physiol. 2014:27:9-17.

42. Vamsi KN, B RV, Kasetti BR, Apparao C. GC-MS analysis of Pharagmytes vallatoroa leaf ethanolic extract. Int Res J Pharm. 2012;3:252-4.

43. Varsha KK, Devendra L, Shilpa G, Priya S, Pandey A, Nampoothiri KM. 2,4-Ditert-butyl phenol as the antifungal, antioxidant bioactive purified from a newly isolated Lactococcus sp. Int J Food Microbiol. 2015;211:44-50.

44. de A Tomaz AC, de Miranda GEC, de Souza MFV, da Cunha EVL. Analysis and characterization of methyl esters of fatty acids of some Gracilaria species. Biochem Syst Ecol. 2012;44:303-6.

45. Kumar P, Narasimhan B, Ramasamy K, Mani V, Mishra R, Majeed A. Synthesis, Antimicrobial, Anticancer Evaluation and QSAR Studies of 3/4-Bromo Benzohydrazide Derivatives. Curr Top Med Chem. 2015:15:1050-64. 